\begin{tabular}{lcl}
\hline Bentham OPEN & The Open Orthopaedics Journal \\
CrossMark & Content list available at: www.benthamopen.com/TOORTHJ/ & DOI: $10.2174 / 1874325001711011049$ \\
\hline
\end{tabular}

RESEARCH ARTICLE

\title{
Application of Tranexamic Acid in Total Knee Arthroplasty - Prospective Randomized Trial
}

Joao Paulo Fernandes Guerreiro ${ }^{1,2,3,}$, Bruno Scatolon Badaro ${ }^{2}$, Jose Rodolfo Martines Balbino ${ }^{2}$, Marcus Vinicius Danieli ${ }^{1,2,3}$, Alexandre Oliveira Queiroz ${ }^{2}$ and Daniele Cristina Cataneo ${ }^{3}$

${ }^{I}$ UNIORT.E Orthopedic Hospital, Londrina, Parana state, Brazil

${ }^{2}$ Londrina Evangelic Hospital, Londrina, Parana state, Brazil

${ }^{3}$ Universidade Estadual Paulista Julio de Mesquita Filho, Botucatu, Sao Paulo state, Brazil

Received: May 20, 2017

Revised: July 14, 2017

Accepted: July 26, 2017

Abstract:

\section{Background:}

The use of tranexamic acid (TXA) in total knee arthroplasty (TKA) has shown good results. Bleeding may cause local complications consequently greater pain and reduced function postoperatively. No study has related the use of TXA to these facts.

\section{Objective:}

The aim was to evaluate the effects of TXA haemoglobin, Western Ontario and McMaster Universities Index (WOMAC), pain intensity and flexion gain after TKA.

\section{Methods:}

43 patients were randomized and then underwent TKA. TXA was applied to 22 of these patients before closure of the joint capsule. Haemoglobin measurements $(\mathrm{mg} / \mathrm{dL})$ were taken preoperatively and 24 and 48 hours after surgery. The WOMAC questionnaire and pain visual analogue scale (VAS) were applied, and flexion gain was measured up to the second postoperative month. Statistical analysis compared the results to determine whether there were differences between the groups for each of the evaluated times.

\section{Results:}

There were differences in favour of the drug 48 hours postoperatively for the haemoglobin variable $(p=0.01)$, in pain evaluation, 24 and 48 hours, postoperatively $(\mathrm{p}<0.01)$ and in flexion gain, 24 hours after surgery $(\mathrm{p}=0.03)$. There were no significant differences between the groups in the haemoglobin evaluation 24 hours postoperatively, in pain assessment 7 days, 21 days and 2 months, postoperatively, in flexion gain 48 hours, 7 days, 21 days and 2 months, postoperatively and in WOMAC after 2 months.

\section{Conclusion:}

In addition to reducing bleeding, topical TXA improved pain and increased flexion gain in the first hours after TKA.

\section{Trial Registration:}

RBR-9b4qgq

Keywords: Arthroplasty, Arthritic knee, Bleeding, Tranexamic acid, Pain, Haemoglobin.

\footnotetext{
* Address correspondence to this author at the UNIORT. E Orthopedic Hospital, Londrina, Parana state, Londrina Evangelic Hospital, Brazil, Tel: +554333770900; E-mail: joaoguerreiro39@yahoo.com.br
} 


\section{INTRODUCTION}

Total knee arthroplasty (TKA) is the ideal surgical option for treating severe pain in the arthritic knee [1]. According to the literature, approximately $20 \%$ of patients with surgical indications have preoperative anaemia and, therefore, are at a relatively higher risk of requiring blood transfusion [2, 3].

Intraoperative homeostatic control is important and can avoid possible procedural and transfusion complications in patients with anaemia in the postoperative period [2, 4]. It is known that blood component administration increases the risk of infections and immune reactions $[4,5]$. Several haemostatic control strategies have proven effective in recent years $[6,7]$. Classical strategies for the control of intraoperative bleeding include the use of a pneumatic tourniquet, anaesthesia and low-pressure haemostasis [4, 8]. Recently, tranexamic acid (TXA) has been used as an adjuvant to such measures [6 - 18]. TXA is an analogue of lysine and inhibits fibrinolysis and blocks, with high affinity, the lysine to plasminogen binding sites, thereby preventing formation of the complex between plasminogen, fibrin and tissue plasminogen activator [19] (Fig. 1). TXA is a synthetic product that is inexpensive and easily accessible [8, 10 - 12], with good results in cardiac surgery. It has attenuated haemostatic disorders for over 20 years [20].
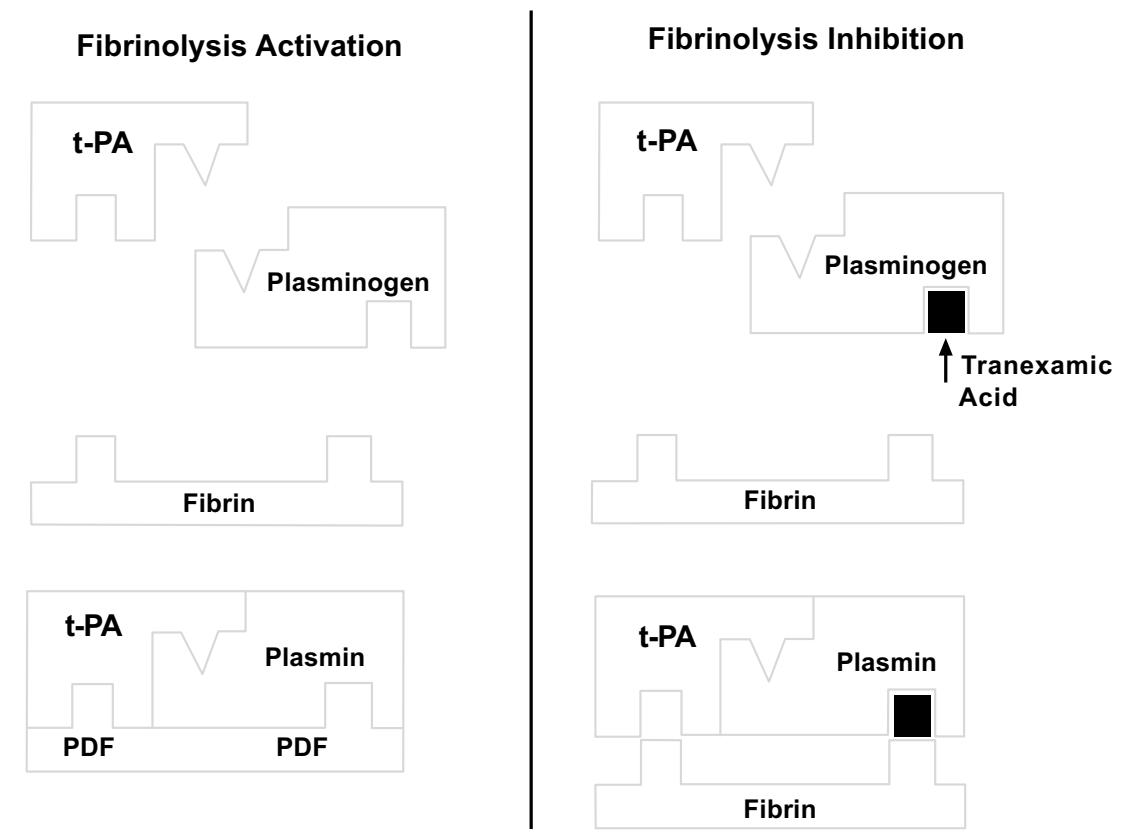

Fig. (1). Action mechanism of tranexamic acid (TXA). The site in plasminogen where fibrin binds is occupied by TXA, preventing fibrinolysis. T-PA - Tissue plasminogen activator; FDP - fibrin degradation products. Source: Santos et al. (19).

Orthopaedics initially hesitated to use this substance, as there was a lack of information regarding the safety of TXA use in relation to thromboembolic events [7, 11, 21, 22]. However, more recent studies have demonstrated the benefits of TXA in TKA, revealing different administration routes and therapeutic dosages [5 - 7, 9, 10, 17, 23$]$.

Intra-articular administration of TXA in TKA has shown good results, effectively reducing the decrease in haemoglobin, the blood loss through drainage and the need for transfusion for up 48 hours, postoperatively [14, 16]. It is known that persistent bleeding during the postoperative period may cause local complications, such as haematoma, seroma and consequently greater pain and reduced function postoperatively [24, 25]. No study has related use of TXA to these facts.

Therefore, the hypothesis of this study was that, in addition to reducing bleeding, the topical application of TXA at the end of surgery before closure of the joint capsule and surgical incision would be effective in controlling pain and improving functional recovery and flexion gain in the postoperative period of TKA.

\section{OBJECTIVE}

The objective was to evaluate the effects of TXA on serum haemoglobin, the Western Ontario and McMaster Universities Index (WOMAC), pain intensity and flexion gain after TKA. 


\section{METHODS}

The study was conducted in the city of Londrina-PR, at the Brotherhood of Santa Casa de Londrina, Philanthropic Hospital (Irmandade da Santa Casa de Londrina, Hospital Filantrópico), a reference in high-complexity orthopaedics and traumatology services within the Unified Health System (Sistema Único de Saúde - SUS). This study was undertaken after approval by the Research Ethics Committee of the institution, which is linked to the National Research Ethics Commission (Comissão Nacional de Ética em Pesquisa - CONEP). This study was approved under protocol number 634815 on 05/05/2014. Trial Registration: RBR-9b4qgq.

A total of 43 patients with indications for TKA, treated at the outpatient clinic of the institution, were selected between June 2014 and October 2015. The selected patients were duly informed about the project and signed terms of free and informed consent. Inclusion criteria were patients of either gender with the presence of tricompartmental knee osteoarthritis with varus deformity, with indications for TKA. Exclusion criteria were patients with major deformities that would lead to bone cuts or release of a more extensive area of soft tissue; presence of inflammatory diseases; patients who had undergone previous surgeries of the same knee; use of anticoagulation medication up to seven days before surgery; and patients with history of atrial fibrillation, deep vein thrombosis or prior pulmonary embolism.

The subjects were divided into 2 groups (Fig. 2): those using TXA and a control group (no applied substance). Allocation was randomized by the surgeon, and the subjects were monitored for 2 months. The groups were named "Control" (21 patients undergoing total knee prosthesis without application of TXA or any other intra-articular sealant substance) and TXA (22 patients undergoing total knee prosthesis and intra-articular application of TXA during the TKA procedure). The dose chosen for topical treatment followed the existing literature data on the use of TXA in total

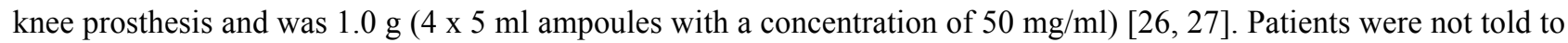
which group they belonged and were completely unaware of this information until the end of the project.

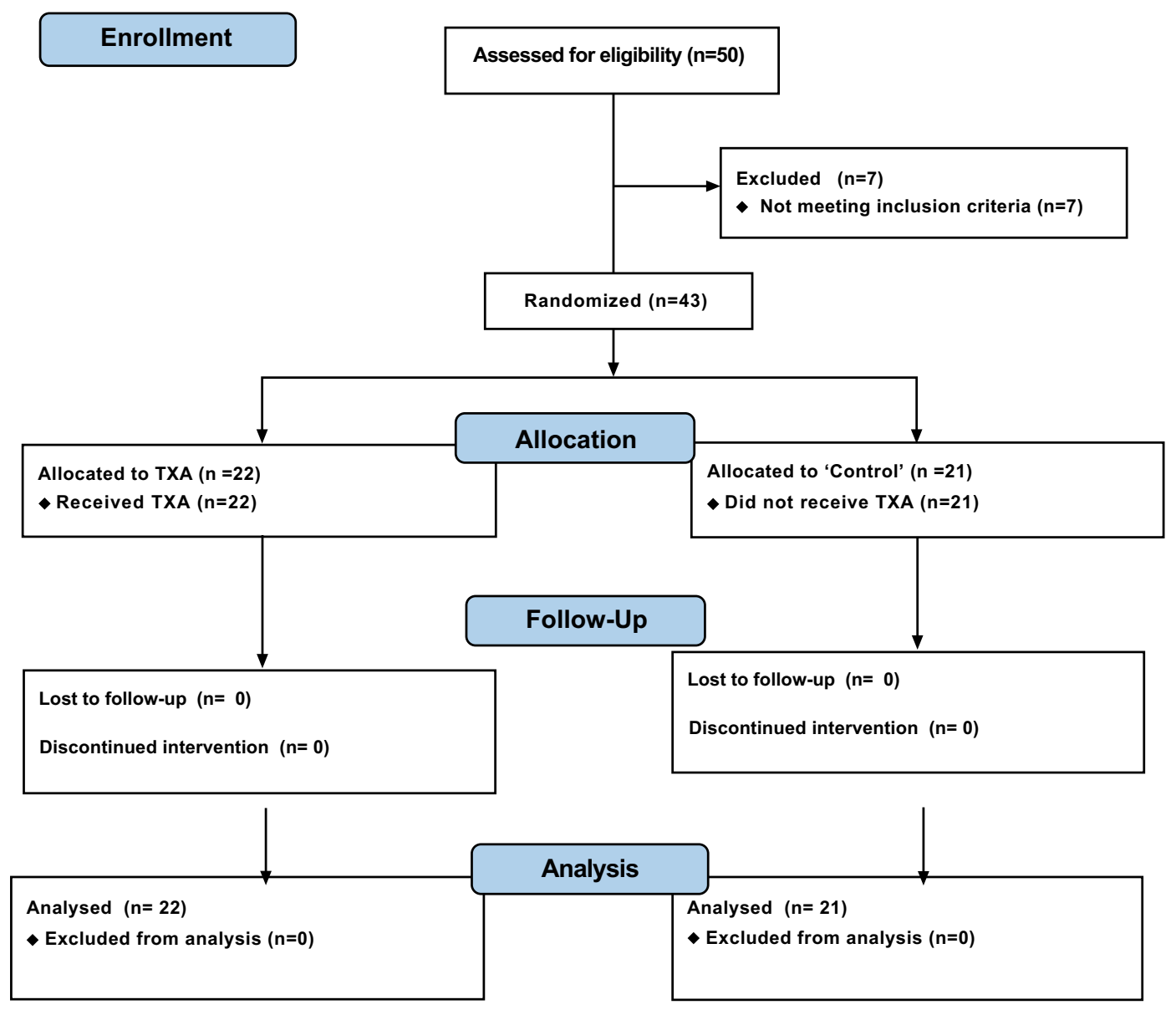

Fig. (2). Flow diagram. 
The following data on the pre- and postoperative periods were recorded (Table 1):

Table 1. Spreadsheet Model used for data collection of the Parameters analysed at the different time intervals (pre- and postoperative).

\begin{tabular}{|c|c|c|c|c|c|c|}
\hline & Pre-operative & 24 h post-operative & 48 h post-operative & 7 days post-operative & 21 days post-operative & 2 months post-operative \\
\hline $\mathrm{Hb}$ & $\mathrm{X}$ & $\mathrm{X}$ & $\mathrm{X}$ & & & \\
\hline Flexion & $\mathrm{X}$ & $\mathrm{X}$ & $\mathrm{X}$ & $\mathrm{X}$ & $\mathrm{X}$ & $\mathrm{X}$ \\
\hline Pain & $\mathrm{X}$ & $\mathrm{X}$ & $\mathrm{X}$ & $\mathrm{X}$ & $\mathrm{X}$ & $\mathrm{X}$ \\
\hline WOMAC & $\mathrm{X}$ & & & & & $\mathrm{X}$ \\
\hline
\end{tabular}

Hb: Haemoglobin, Flexion: Flexion gain, Pain: Pain based on a visual analogue scale, WOMAC: Western Ontario and McMaster Universities Index.

1. Haemoglobin $(\mathrm{Hb})$ levels preoperatively and 24 and 48 hours after surgery.

2. Reports of clinical flexion gain examination using a goniometer for evaluations 24 hours, 48 hours, 7 days, 21 days and 2 months after surgery.

3. Pain evaluation using a visual analogue scale (VAS), which consists of a 1-dimensional instrument containing an 11-point scale (0-10), where zero is rated as no pain and 10 the worst pain one has ever felt. Patients selected a single number that best represented the intensity of their pain at the following postoperative time intervals: 24 and 48 hours, 7 days, 21 days and 2 months after surgery.

4. Evaluations of knee function, preoperatively and 2 months after surgery, using the "WOMAC" instrument, were translated and validated for the Portuguese language [28].

The surgical technique was used documented within the current literature, with subarachnoid anesthesia, patellar medial access and application of TXA all over the exposed joint in the selected cases using a syringe (Fig. 3) and maintained for 5 minutes. After this period, the joint capsule and incision were closed without drain (Fig. 4). All procedures were performed by the same surgeon and with the same instrument and implant (Meta Bio Ltd., Rio Claro, São Paulo, Brazil).

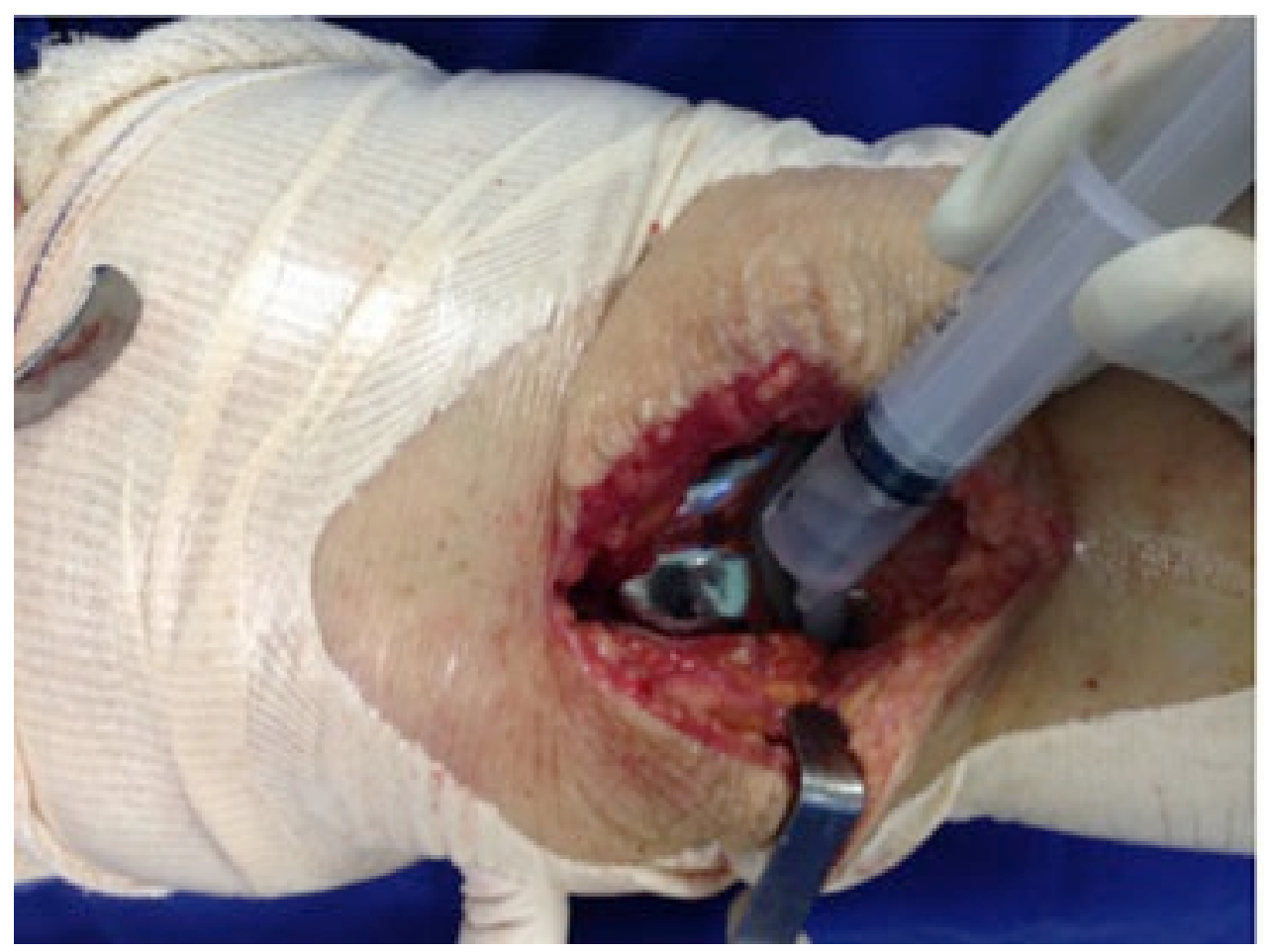

Fig. (3). Application of tranexamic acid before capsule closure.

Postoperatively, during hospitalization, the analgesics used included $1 \mathrm{~g}$ of intravenous dipyrone every 6 hours and $50 \mathrm{mg}$ of tramadol hydrochloride every 8 hours. Patients with pain scores above 7 on the numerical pain scale received $4 \mathrm{mg}$ of intravenous morphine every 4 hours. After discharge, $1 \mathrm{~g}$ of dipyrone was prescribed orally every 6 hours in case of pain, and $50 \mathrm{mg}$ of tramadol hydrochloride was administered orally every 6 hours if the pain remained with the 
use of dipyrone. All patients received as prophylaxis for deep venous thrombosis a dose of $40 \mathrm{mg}$ of enoxaparin 12,24 and 48 hours after surgery and were prescribed $10 \mathrm{mg}$ Rivaroxaban daily for 10 days at home. Antibiotic prophylaxis was achieved with $2 \mathrm{~g}$ intravenous cefazolin during anaesthetic induction and $1 \mathrm{~g}$ of cefazolin every 8 hours for 48 hours. The dressing was changed in the hospital on the $2^{\text {nd }}$ postoperative day, every day at home and at the clinic on the $7^{\text {th }}$ day. The stitches were removed on the $21^{\text {st }}$ postoperative day. Patients used a walker for 21 days with a full load from the $2^{\text {nd }}$ postoperative day. Physical therapy was also initiated on admission and was maintained until the second month, postoperatively, 3 times a week with a physical therapy protocol focusing on analgesia, gain in flexion and walking training. Radiological knee examinations were performed in the immediate post-operative period and upon return to the clinic 2 months later.

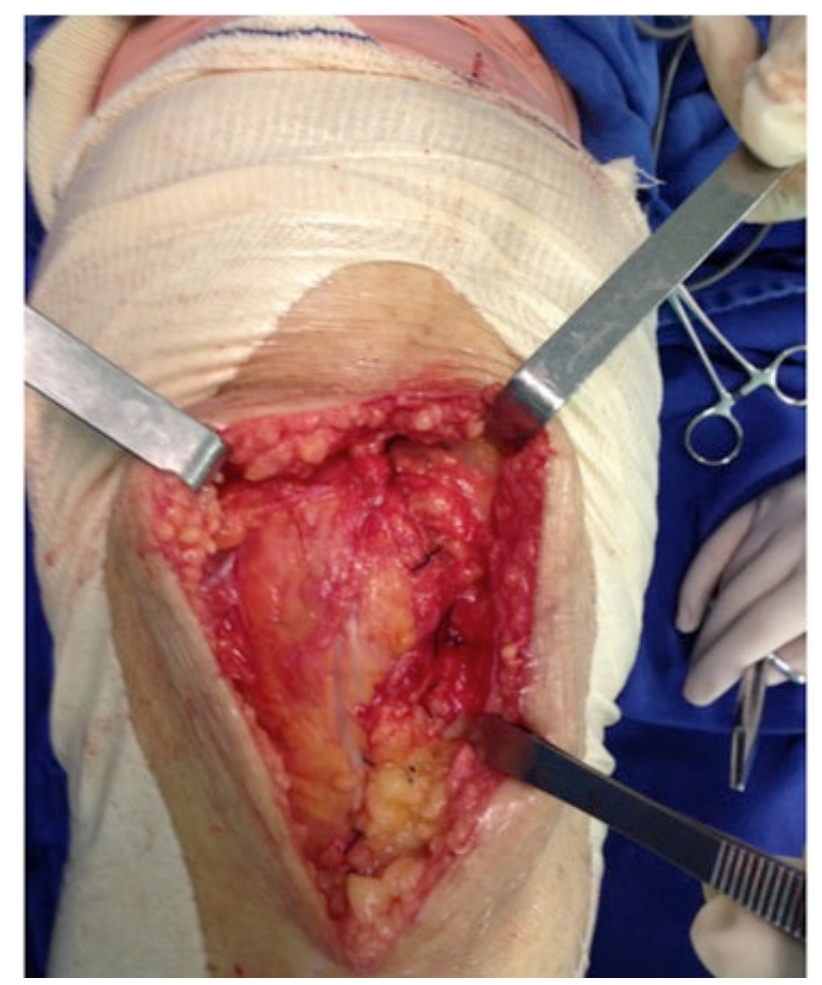

Fig. (4). Closing of the joint capsule.

\section{STATISTICAL ANALYSIS}

Calculation of the statistical power of the sample was achieved using the sampsi command of the STATA software package, version 11, based on the method proposed by Frison and Pocock [29] for a group comparison design with repeated measures. 5\% significance level was adopted, and upon varying the test power, we found that 20 patients per group would guarantee a power of at least $95 \%$ for comparisons [29].

Comparisons between the 2 groups and times with respect to all variables were performed using mixed effect linear regression models (random and fixed effects) [30]. The orthogonal contrast post-test was used for comparisons. Intergroup comparisons regarding changes in $\mathrm{Hb}$ and WOMAC times were performed using Student's t test. The significance level adopted for all comparisons was $5 \%$.

\section{RESULTS}

The mean age of the participants was $68.74(55-86)$ years. The mean ages were $68.36(55-81)$ years in the TXA group and $69.14(55-81)$ years in the control group. The average operating time was 92.9 (80-105) minutes; 94.3 (80-105) minutes in the TXA group and 91.5 (85-95) minutes in the control group. There were 11 male patients; 4 in the TXA group and 7 in the control group Table (1).

None of the study participants required blood transfusion. The criterion used to determine transfusion was a haemoglobin value of less than $7 \mathrm{mg} / \mathrm{dl}$ in symptomatic patients during the postoperative period. One patient in the TXA group presented dehiscence in the surgical wound and superficial infection, which was treated with dressings and 
oral antibiotics until their total healing. There were no cases of thromboembolism.

Tables (2 and $\mathbf{3}$ ) shows that there were statistically significant differences in favour of the group using TXA 48 hours postoperatively for the haemoglobin variable $(\mathrm{p}=0.01), 24$ and 48 hours postoperatively for pain evaluation ( $\mathrm{p}$ $<0.01)$ and 24 hours postoperatively for flexion gain $(p=0.03)$. There were no significant differences between the groups in the haemoglobin evaluation 24 hours postoperatively, in pain assessment 7 days, 21 days and 2 months postoperatively, in flexion gain 48 hours, 7 days, 21 days and 2 months postoperatively and in the WOMAC questionnaire 2 months postoperatively.

Table 2. Mean, maximum and minimum values for age, gender distribution and operating time among patients.

\begin{tabular}{|c|c|c|c|}
\hline & TXA Group & Control Group & Total \\
\hline Number of patients & 22 & 21 & 43 \\
\hline Age (years) & $68.36(55-86)$ & $69.14(55-81)$ & $68.74(55-86)$ \\
\hline Gender $(\mathrm{M} / \mathrm{F})$ & $4 / 18$ & $7 / 14$ & $11 / 32$ \\
\hline Operating time (minutes) & $94.3(80-105)$ & $91.5(85-95)$ & $92.9(80-105)$ \\
\hline
\end{tabular}

Table 3. Comparison between the TXA and control groups.

\begin{tabular}{|c|c|c|c|}
\hline & TXA Group & Control Group & P Value \\
\hline Fall in $\mathrm{Hb} 24 \mathrm{~h}$ & $0.98(0.10-2.10)$ & $1.38(0.20-3.50)$ & $p>0.05(0.10)$ \\
\hline Fall in $\mathrm{Hb} 48 \mathrm{~h}$ & $1.53(0.40-3.30)$ & $2.28(0.60-4.00)$ & $\begin{array}{c}\mathrm{p}<0.05 \\
(0.01)\end{array}$ \\
\hline Mean pain $24 \mathrm{~h}$ & $5.23(1-9)$ & $6.33(4-8)$ & $\begin{array}{l}\mathrm{p}<0.05 \\
(<0.01)\end{array}$ \\
\hline Mean pain $48 \mathrm{~h}$ & $2.45(0-4)$ & $3.81(2-6)$ & $\begin{array}{l}\mathrm{p}<0.05 \\
(<0.01)\end{array}$ \\
\hline Mean pain 7 days & $1.82(0-3)$ & $2.38(1-3)$ & $p>0.05(0.08)$ \\
\hline Mean pain 21 days & $1.32(0-3)$ & $1.67(0-3)$ & $p>0.05(0.26)$ \\
\hline Mean pain 2 months & $1.05(0-4)$ & $1.33(0-3)$ & $\mathrm{p}>0.05(0.35)$ \\
\hline Flexion gain $24 \mathrm{~h}$ & $71.82(50-90)$ & $63.81(40-90)$ & $\begin{array}{c}p<0.05 \\
(0.03)\end{array}$ \\
\hline Flexion gain $48 \mathrm{~h}$ & $80.45(60-100)$ & $80.00(60-90)$ & $\begin{array}{c}p>0.05 \\
(0.88)\end{array}$ \\
\hline Flexion gain 7 days & $87.95(60-100)$ & $86.43(80-100)$ & $p>0.05(0.65)$ \\
\hline Flexion gain 21 days & $94.77(80-110)$ & $95.48(80-110)$ & $\begin{array}{c}p>0.05 \\
(0.86)\end{array}$ \\
\hline Flexion gain 2 months & $100.23(80-120)$ & $97.38(80-115)$ & $\begin{array}{c}p>0.05 \\
(0.42)\end{array}$ \\
\hline WOMAC 2 months & $45.77(21-60)$ & $45.10(33-54)$ & $\begin{array}{c}p>0.05 \\
(0.19)\end{array}$ \\
\hline
\end{tabular}

TXA: Tranexamic acid, Hb: Haemoglobin, WOMAC: Western Ontario and McMaster Universities Index.

\section{DISCUSSION}

The topical administration of $1 \mathrm{~g}$ of TXA was effective in reducing bleeding based on the haemoglobin level. This fact, demonstrated again in this study, was already known [16, 26]. In published studies, the most common administration route for the application of TXA in TKA has been intravenous. Intravenous administration in a single dose or repeated doses was used initially in orthopaedic procedures, based on previous studies in cardiac surgery [17]. However, there is evidence demonstrating that only a fraction of the injected drug reaches the target tissue, which in turn reduces its effectiveness [10]; that up to $95 \%$ of the drug can be eliminated in the urine; and that in patients with impaired kidney function, the dosage needs to be corrected [19]. When administered in high doses or injected quickly, minor gastrointestinal symptoms, such as nausea and vomiting, have been reported [31, 32]. Intraarticular use generates cost savings because lower doses can be used, without systemic side effects, and also because the surgeon can apply it him- or herself.

Pain, as measured on the visual analogue scale, showed a statistically significant difference (p $<0.01)$ from 24 to 48 hours postoperatively in the group using TXA. The flexion range of motion analysis showed a statistically significant 
difference in the group that used TXA $(\mathrm{p}=0.03)$. Pain control and range of motion gain are important goals after the knee arthroplasty procedure. Immediate postoperative pain impairs mobility and reduces the patient's ability to cooperate with rehabilitation treatment [33]. When experiencing postoperative pain, the patient's difficulty in activities of daily living, physical dependence and motion restriction of the operated limb increase their anxiety and discouragement, which can be a complicating factor in the rehabilitation process and may also increase the patient's perception of pain [34]. Alternatively, the use of opioid analgesics for pain control after surgery is recommended; however, a systematic review determined that they are associated with several undesirable side effects, including nausea, vomiting, hypotension, urinary retention, delirium and increased infection rates, which consequently generate an increase in the length of hospital stay and an additional financial cost to the procedure [18]. The use of a less aggressive surgical approach, for example, is now widespread for this purpose but may lead to increased bleeding [35]. In a previous study, our group showed that the application of platelet-rich plasma in total knee replacement surgery reduced postoperative pain but did not reduce bleeding [36]. The literature does not show that TXA is effective in controlling pain or movement gain, as our study has shown, in the first 48 hours after the procedure.

The result obtained in the first 48 hours after the procedure, with advantages in relation to pain and gain in range of motion, was not maintained in the outpatient evaluations in the first months. Knee function, analysed using the WOMAC questionnaire, did not show a better gain in that period than that of the control group.

We believe that the surgeon's and the researcher's knowledge regarding which subjects were cases and which were controls during the procedure and the short follow-up time may be considered weaknesses of the study. A multicentre study with a greater number of individuals may provide better evidence on the subject.

\section{CONCLUSION}

In the manner in which it was used, in addition to reducing bleeding, TXA improved pain and increased flexion gain in the first hours after TKA. There were no differences between groups in terms of pain evaluation, flexion gain and knee function beyond the first 48 hours after the procedure.

\section{ETHICS APPROVAL AND CONSENT TO PARTICIPATE}

Not applicable.

\section{HUMAN AND ANIMAL RIGHTS}

No Animals/Humans were used for studies that are base of this research.

\section{CONSENT FOR PUBLICATION}

Not applicable.

\section{CONFLICT OF INTEREST}

The authors declare no conflict of interest, financial or otherwise.

\section{ACKNOWLEDGEMENTS}

Declared none.

\section{REFERENCES}

[1] Kurtz S, Ong K, Lau E, Mowat F, Halpern M. Projections of primary and revision hip and knee arthroplasty in the United States from 2005 to 2030. J Bone Joint Surg Am 2007; 89(4): 780-5.

[PMID: 17403800]

[2] Bierbaum BE, Callaghan JJ, Galante JO, Rubash HE, Tooms RE, Welch RB. An analysis of blood management in patients having a total hip or knee arthroplasty. J Bone Joint Surg Am 1999; 81(1): 2-10. [http://dx.doi.org/10.2106/00004623-199901000-00002] [PMID: 9973048]

[3] Myers E, O’Grady P, Dolan AM, Dolan AM. The influence of preclinical anaemia on outcome following total hip replacement. Arch Orthop Trauma Surg 2004; 124(10): 699-701.

[http://dx.doi.org/10.1007/s00402-004-0754-6] [PMID: 15517315]

[4] Spahn DR. Anemia and patient blood management in hip and knee surgery: A systematic review of the literature. Anesthesiology 2010; 113(2): 482-95

[http://dx.doi.org/10.1097/ALN.0b013e3181e08e97] [PMID: 20613475] 
[5] Henry DA, Carless PA, Moxey AJ, et al. Anti-fibrinolytic use for minimising perioperative allogeneic blood transfusion. Cochrane Database Syst Rev 2011; 3: CD001886. [http://dx.doi.org/10.1002/14651858.CD01886.pub4]

[6] Alshryda S, Sarda P, Sukeik M, Nargol A, Blenkinsopp J, Mason JM. Tranexamic acid in total knee replacement: A systematic review and meta-analysis. J Bone Joint Surg Br 2011; 93(12): 1577-85. [http://dx.doi.org/10.1302/0301-620X.93B12.26989] [PMID: 22161917]

[7] Dunn CJ, Goa KL. Tranexamic acid: A review of its use in surgery and other indications. Drugs 1999; 57(6): 1005-32. [http://dx.doi.org/10.2165/00003495-199957060-00017] [PMID: 10400410]

[8] Banerjee S, Issa K, Kapadia BH, et al. Intraoperative nonpharmacotherapeutic blood management strategies in total knee arthroplasty. J Knee Surg 2013; 26(6): 387-93.

[http://dx.doi.org/10.1055/s-0033-1353993] [PMID: 23959578]

[9] Kagoma YK, Crowther MA, Douketis J, Bhandari M, Eikelboom J, Lim W. Use of antifibrinolytic therapy to reduce transfusion in patients undergoing orthopedic surgery: a systematic review of randomized trials. Thromb Res 2009; 123(5): 687-96. [http://dx.doi.org/10.1016/j.thromres.2008.09.015] [PMID: 19007970]

[10] Ishida K, Tsumura N, Kitagawa A, et al. Intra-articular injection of tranexamic acid reduces not only blood loss but also knee joint swelling after total knee arthroplasty. Int Orthop 2011; 35(11): 1639-45. [http://dx.doi.org/10.1007/s00264-010-1205-3] [PMID: 21253725]

[11] Panteli M, Papakostidis C, Dahabreh Z, Giannoudis PV. Topical tranexamic acid in total knee replacement: A systematic review and metaanalysis. Knee 2013; 20(5): 300-9.

[http://dx.doi.org/10.1016/j.knee.2013.05.014] [PMID: 23815893]

[12] Zhang H, Chen J, Chen F, Que W. The effect of tranexamic acid on blood loss and use of blood products in total knee arthroplasty: A metaanalysis. Knee Surg Sports Traumatol Arthrosc 2012; 20(9): 1742-52. [http://dx.doi.org/10.1007/s00167-011-1754-z] [PMID: 22065294]

[13] MacGillivray RG, Tarabichi SB, Hawari MF, Raoof NT. Tranexamic acid to reduce blood loss after bilateral total knee arthroplasty: A prospective, randomized double blind study. J Arthroplasty 2011; 26(1): 24-8. [http://dx.doi.org/10.1016/j.arth.2009.11.013] [PMID: 20171048]

[14] Wang H, Shen B, Zeng Y. Blood loss and transfusion after topical tranexamic acid administration in primary total knee arthroplasty. Orthopedics 2015; 38(11): e1007-16.

[http://dx.doi.org/10.3928/01477447-20151020-10]

[15] Ahlberg A, Eriksson O, Kjellman H. Diffusion of tranexamic acid to the joint. Acta Orthop Scand 1976; 47(5): $486-8$. [http://dx.doi.org/10.3109/17453677608988725] [PMID: 998182]

[16] Wong J, Abrishami A, El Beheiry H, et al. Topical application of tranexamic acid reduces postoperative blood loss in total knee arthroplasty: A randomized, controlled trial. J Bone Joint Surg Am 2010; 92(15): 2503-13. [http://dx.doi.org/10.2106/JBJS.I.01518] [PMID: 21048170]

[17] Good L, Peterson E, Lisander B. Tranexamic acid decreases external blood loss but not hidden blood loss in total knee replacement. Br J Anaesth 2003; 90(5): 596-9. [http://dx.doi.org/10.1093/bja/aeg111] [PMID: 12697586]

[18] Gillette BP, Maradit KH, Duncan CM, et al. Economic impact of tranexamic acid in healthy patients undergoing primary total hip and knee arthroplasty. J Arthroplasty 2013; 28(8)(Suppl.): 137-9.

[http://dx.doi.org/10.1016/j.arth.2013.04.054] [PMID: 23886409]

[19] Santos AT, Splettstosser JC, Warpechowski P, Gaidzinski MM. Antifibrinolytics and cardiac surgery with cardiopulmonary bypass. Rev Bras Anestesiol 2007; 57(5): 549-64. [http://dx.doi.org/10.1590/S0034-70942007000500011] [PMID: 19462132]

[20] Pugh SC, Wielogorski AK. A comparison of the effects of tranexamic acid and low-dose aprotinin on blood loss and homologous blood usage in patients undergoing cardiac surgery. J Cardiothorac Vasc Anesth 1995; 9(3): 240-4. [http://dx.doi.org/10.1016/S1053-0770(05)80314-3] [PMID: 7545448]

[21] Krivokuca I, Lammers JW. Recurrent pulmonary embolism associated with a hemostatic drug: tranexamic acid. Clin Appl Thromb Hemost 2011; 17(1): 106-7.

[http://dx.doi.org/10.1177/1076029609340902] [PMID: 19833620]

[22] Taparia M, Cordingley FT, Leahy MF. Pulmonary embolism associated with tranexamic acid in severe acquired haemophilia. Eur J Haematol 2002; 68(5): 307-9. [http://dx.doi.org/10.1034/j.1600-0609.2002.01607.x] [PMID: 12144537]

[23] Cid J, Lozano M. Tranexamic acid reduces allogeneic red cell transfusions in patients undergoing total knee arthroplasty: Results of a metaanalysis of randomized controlled trials. Transfusion 2005; 45(8): 1302-7. [http://dx.doi.org/10.1111/j.1537-2995.2005.00204.x] [PMID: 16078916]

[24] Everts PA, Devilee RJ, Brown MC, et al. Platelet gel and fibrin sealant reduce allogeneic blood transfusions in total knee arthroplasty. Acta Anaesthesiol Scand 2006; 50(5): 593-9. 
[http://dx.doi.org/10.1111/j.1399-6576.2006.001005.x] [PMID: 16643230]

[25] Berghoff WJ, Pietrzak WS, Rhodes RD. Platelet-rich plasma application during closure following total knee arthroplasty. Orthopedics 2006; 29(7): 590-8.

[PMID: 16866090]

[26] Yang ZG, Chen WP, Wu LD. Effectiveness and safety of tranexamic acid in reducing blood loss in total knee arthroplasty: A meta-analysis. J Bone Joint Surg Am 2012; 94(13): 1153-9.

[http://dx.doi.org/10.2106/JBJS.K.00873] [PMID: 22623147]

[27] Georgiadis AG, Muh SJ, Silverton CD, Weir RM, Laker MW. A prospective double-blind placebo controlled trial of topical tranexamic acid in total knee arthroplasty. J Arthroplasty 2013; 28(8)(Suppl.): 78-82. [http://dx.doi.org/10.1016/j.arth.2013.03.038] [PMID: 23906869]

[28] Fernandes MI. Translation and validation of the specific quality of life questionnaire for osteoarthritis WOMAC (Western Ontario McMaster Universities) for portuguese language [thesis]. Available from http://repositorio.unifesp.br/handle/11600/19401 $2003 ; 103$.

[29] Frison L, Pocock SJ. Repeated measures in clinical trials: analysis using mean summary statistics and its implications for design. Stat Med 1992; 11(13): 1685-704. [http://dx.doi.org/10.1002/sim.4780111304] [PMID: 1485053]

[30] Schall R. Estimation in generalized linear models with random effects. Biometrika 1991; 78(4): $719-27$. [http://dx.doi.org/10.1093/biomet/78.4.719]

[31] Andersson L, Nilsson IM, Niléhn JE, Hedner U, Granstrand B, Melander B. Experimental and clinical studies on AMCA, the antifibrinolytically active isomer of p-aminomethyl cyclohexane carboxylic acid. Scand J Haematol 1965; $2(3)$ : $230-47$. [http://dx.doi.org/10.1111/j.1600-0609.1965.tb01300.x] [PMID: 5834403]

[32] Eriksson O, Kjellman H, Pilbrant A, Schannong M. Pharmacokinetics of tranexamic acid after intravenous administration to normal volunteers. Eur J Clin Pharmacol 1974; 7(5): 375-80. [http://dx.doi.org/10.1007/BF00558210] [PMID: 4422030]

[33] Moucha CS, Weiser MC, Levin EJ. Current strategies in anesthesia and analgesia for total knee arthroplasty. J Am Acad Orthop Surg 2016; 24(2): 60-73. [http://dx.doi.org/10.5435/JAAOS-D-14-00259] [PMID: 26803543]

[34] Ferreira AH, Godoy PB, Oliveira NR, et al. Investigation of depression, anxiety and quality of life in patients with knee osteoarthritis: A comparative study. Rev Bras Reumatol 2015; 55(5): 434-8. [http://dx.doi.org/10.1016/j.rbr.2015.03.001] [PMID: 26198010]

[35] Varela-Egocheaga JR, Suárez-Suárez MA, Fernández-Villán M, González-Sastre V, Varela-Gómez JR, Rodríguez-Merchán C. Minimally invasive subvastus approach: improving the results of total knee arthroplasty: A prospective, randomized trial. Clin Orthop Relat Res 2010; 468(5): 1200-8.

[http://dx.doi.org/10.1007/s11999-009-1160-8] [PMID: 19911245]

[36] Guerreiro JP, Danieli MV, Queiroz AO, Deffune E, Ferreira RR. Platelet-rich plasma (PRP) applied during total knee arthroplasty. Rev Bras Ortop 2015; 50(2): 186-94.

[http://dx.doi.org/10.1016/j.rboe.2015.02.014] [PMID: 26229915]

(C) 2017 Guerreiro et al.

This is an open access article distributed under the terms of the Creative Commons Attribution 4.0 International Public License (CC-BY 4.0), a copy of which is available at: https://creativecommons.org/licenses/by/4.0/legalcode. This license permits unrestricted use, distribution, and reproduction in any medium, provided the original author and source are credited. 